\title{
Dual-fuel operation of gasoline and natural gas in a turbocharged engine
}

\author{
Eshan Singh ${ }^{\mathrm{a}, *}$, Kai Morganti ${ }^{\mathrm{b}}$, Robert Dibble $^{\mathrm{a}}$ \\ ${ }^{a}$ Clean Combustion Research Center, King Abdullah University of Science and Technology, Thuwal, Saudi Arabia \\ ${ }^{b}$ Fuel Technology R\&D Division, Saudi Aramco Research \& Development Center, Dhahran, Saudi Arabia
}

\begin{abstract}
Natural gas is a high-octane fuel that produces lower $\mathrm{CO}_{2}$ emissions per kilowatt hour than liquid transport fuels, with essentially zero sulfur emissions. Historically, natural gas has mostly been used in power generation and industrial applications. However, there has been a recent shift towards employing natural gas in the transport sector. In many developing countries, existing vehicles are retrofitted with compressed natural gas (CNG) systems, enabling operation on both gasoline and natural gas (and theoretical mixtures thereof). This work examines the effect of leveraging the secondary natural gas fuel system on the performance, efficiency and broader environmental impact of a high specific output gasoline engine. Firstly, mixture sweeps are presented for varying gasoline/natural gas ratios (100\% gasoline to $100 \%$ natural gas) at wide open throttle (WOT) with both fixed and variable spark timing. This baseline information is then used to optimize the engine calibration for varying gasoline/natural gas ratios over a wider range of operating conditions. Finally, the $\mathrm{CO}_{2}$-equivalent emissions are computed to elucidate the broader environmental impact of an optimized gasoline/natural gas vehicle. This study suggests that more advanced control systems which enable vehicles to use both gasoline and natural gas simultaneously may provide a range of social, economic and environmental benefits.
\end{abstract}

Keywords: High-octane gasoline, Greenhouse gas emissions, Methane, Natural Gas, Well-to-wheel assessment, Octane-on-Demand

\section{Introduction}

Natural gas is a high-octane fuel $(\mathrm{RON}>130)$ that produces $26 \%$ lower $\mathrm{CO}_{2}$ emissions per kilowatt hour than gasoline, with essentially zero sulfur emissions [1]. Historically, natural gas has mostly been used in power generation and industrial applications. However, there has been a recent shift towards employing this fuel in the transport sector in both developed and developing countries. As an example, the size of the global natural gas vehicle fleet has increased by an order of magnitude over last decade [2]. Many developing

\footnotetext{
*Corresponding author

Email address: eshan.singh@kaust.edu.sa (Eshan Singh)
} 
countries, such as Argentina, China, India, Iran and Pakistan have experienced major growth in natural gas and liquefied petroleum gas (LPG) vehicles, with many projections suggesting future growth will be even more rapid [3-6].

The global natural gas vehicle fleet has largely been expanded by retrofitting compressed natural gas (CNG) systems into vehicles originally designed to operate on gasoline [7]. Since gasoline engines are not optimized for natural gas, the engine control systems are unable to account for variations in the fuel properties. This can be problematic at certain operating conditions, particularly when starting the engine. The original gasoline fuel system therefore remains operational, and the vehicle is operated in a bi-fuel mode [8]. Once the engine has reached a suitable temperature, the combustion switches from gasoline to natural gas. There are two major advantages of such systems. Firstly, such systems enable reductions in $\mathrm{CO}_{2}$ emissions to be achieved from older vehicles, which represent the majority of the fleet in developing countries. Secondly, natural gas is widely available, and is generally of lower cost than conventional liquid transport fuels.

Nevertheless, engines operated on gaseous fuels generally provide lower specific power outputs due to the reduced volumetric efficiency (Figure 1), as well as slower charge burning rates. Recent work on gaseous fueled engines has attempted to offset these issues by directly injecting the fuel into the combustion chamber, often in the liquid phase $[9,10]$. Such systems have benefited both engine efficiency and emissions. But since direct injection systems must be operated at high pressures, there is a cost penalty associated with their implementation. Attempts to improve the charge burning rates of natural gas via the addition of hydrogen have also delivered higher engine efficiency [11-13]. But this also introduces further cost and complexity into the vehicle.

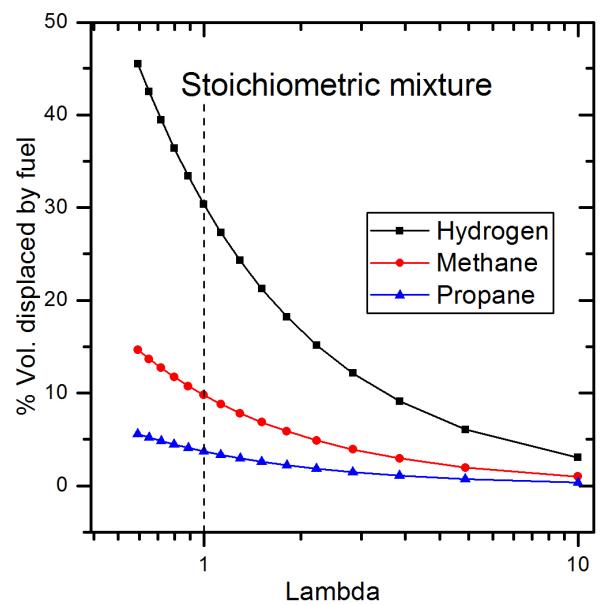

Figure 1: Volume of intake air displaced by different gaseous fuels as a function of relative air-fuel ratio $(\lambda)$.

To overcome the deficiencies of traditional bi-fuel engines, one must consider several issues. Firstly, 
gasoline engine operation is rarely knock limited at low engine loads, but is often extremely knock limited at intermediate and higher engine loads $[14,15]$. The latter could be addressed by operating the engine on natural gas, which provides considerably higher-octane quality (RON $>130)$. This would also remove the need to operate the engine slightly rich of stoichiometry to protect various hardware from excessive temperatures, thereby enabling optimal conversion of carbon monoxide $(\mathrm{CO})$ and unburned hydrocarbon emissions by the three-way catalyst at all times [16]. But operating the engine on natural gas at low loads often provides lower efficiency than gasoline due to the non-optimized combustion system, e.g. insufficient spark advance to offset the lower charge burning rates, a lower compression ratio, and in-cylinder motion that is not optimized for gaseous fuels [8].

Few studies have examined the optimal use of gasoline and gaseous fuels in the same spark-ignition engine. Pipitone and Beccari [16] demonstrated that efficiency improvements of up to $5.5 \%$ could be achieved by operating the engine on a 50-50 mixture of gasoline and natural gas, with a reduction of less than $3 \%$ in the engine power. Studies examining gasoline-propane mixtures have also demonstrated improved engine efficiency, improved emissions and no loss of power compared to the same engine operated on gasoline [17]. Other studies were able to achieve extremely high engine loads of 29 bar brake mean effective pressure (BMEP) with just 30\% natural gas in gasoline. Collectively, the literature suggests that leveraging natural gas to make the engine more efficient in its use of gasoline offers several key benefits, particularly if the vehicle is already equipped with both fuels, as is the case in bi-fuel vehicles.

This work therefore aims to study the leveraging effect of port-injected methane (used as a surrogate for natural gas) on a high specific output, direct injected gasoline engine. Firstly, a conventional dual-fuel mode without any optimization for natural gas is investigated to observe the effects of fuel composition on important engine performance attributes. Secondly, having knowledge of potential improvements, natural gas is used as a leveraging fuel to enhance the octane quality of a commercial gasoline. This approach is similar to the Octane-on-Demand concept, which utilizes higher-octane fuels to expand the operating envelope of the engine and improve high load engine efficiency [18-22]. This concept does not appear to have been examined previously for a liquid/gaseous fuel combination. Finally, the $\mathrm{CO}_{2}$-equivalent emissions are computed to elucidate the broader environmental impact of an optimized gasoline/natural gas vehicle.

\section{Experimental Methods}

\subsection{Engine Hardware}

A single cylinder research engine equipped with a pent-roof combustion chamber and four-valve cylinder head was used in this study. The engine has multiple options for fuel delivery, including direct injection (DI) and port-fuel injection (PFI) systems. In this study, the DI system was used to deliver gasoline to the engine, while the PFI system was used to deliver methane to the engine (Figure 2). Fuel stratification effects 
were minimized by maintaining the start of injection (SOI) for the DI and PFI systems at 300 crank angle degrees before top dead center (CAD bTDC). The engine intake pressure was boosted using an electrically driven supercharger. The in-cylinder pressure was measured with a piezoelectric pressure transducer in increments of 0.1 CAD. This was used to compute the heat release, combustion phasing, knock intensity and indicated mean effective pressure (IMEP). The engine-out exhaust emissions of carbon monoxide (CO), carbon dioxide $\left(\mathrm{CO}_{2}\right)$, nitric oxide $(\mathrm{NO})$, nitrogen oxides $\left(\mathrm{NO}_{X}\right)$, oxygen $\left(\mathrm{O}_{2}\right)$, methane $\left(\mathrm{CH}_{4}\right)$ and other unburned hydrocarbons (HCs) were measured with an AVL AMA i60 gas analyzer. A Flame Ionization Detector (FID) was used for hydrocarbon measurement, a Nondispersive infrared (NDIR) sensor was used for $\mathrm{CO}$ and $\mathrm{CO}_{2}$ measurement, and a Chemi-Luminescence Detector (CLD) was used for NO measurements. The full engine specifications are summarized in Table 1.

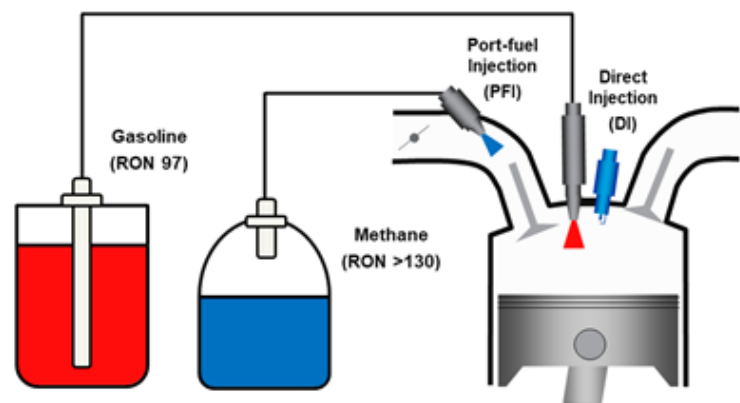

Figure 2: Schematic of the dual injection system fitted to the test engine. The direct injection (DI) system was used to deliver gasoline (red) to the engine, while the port-fuel injection (PFI) system was used to deliver methane (blue) to the engine.

Table 1: Specification of the single cylinder research engine used in this study.

$\begin{array}{lr}\text { Displacement } & 454 \mathrm{cc} \\ \text { Bore } & 82 \mathrm{~mm} \\ \text { Stroke } & 86 \mathrm{~mm} \\ \text { Compression ratio } & 9.7: 1 \\ \text { Direct injection (DI) pressure } & 130 \mathrm{bar} \\ \text { Port-fuel injection (PFI) pressure } & 6 \mathrm{bar} \\ \text { Exhaust valve open (EVO) } & 123 \mathrm{CAD} \text { aTDC } \\ \text { Exhaust valve close (EVC) } & 337 \text { CAD bTDC } \\ \text { Intake valve open (IVO) } & 340 \mathrm{CAD} \text { aTDC } \\ \text { Intake valve close (IVC) } & 130 \mathrm{CAD} \text { bTDC }\end{array}$




\subsection{Test Fuels}

A reference gasoline with a Research octane number (RON) of 97.5 was used in this study. This fuel is representative of a Euro $\mathrm{V}$ gasoline, and was composed of $5 \%$ ethanol and $30 \%$ aromatics by volume. The key fuel properties and distillation characteristics for the reference gasoline are presented in Table 2 and Figure 3, respectively. Methane, with a purity of $99.9 \%$, was used as the high-octane gaseous fuel $($ RON $>130)$. Methane serves as a surrogate fuel for natural gas, which is primarily composed of methane. The lower heating value (LHV) and density of methane are assumed to be $50 \mathrm{MJ} / \mathrm{kg}$ and $0.716 \mathrm{~kg} / \mathrm{m}^{3}$, respectively.

Table 2: Key fuel properties of the reference gasoline.

\begin{tabular}{lr}
\hline Research octane number (RON) & 97.5 \\
Motor octane number (MON) & 86.6 \\
Specific Gravity (SG) & 0.7485 \\
Lower heating value MJ/kg & 42.4 \\
Energy density (MJ/L) & 31.7 \\
Aromatics $(\% \mathrm{v} / \mathrm{v})$ & 30.5 \\
Olefins $(\% \mathrm{v} / \mathrm{v})$ & 8.2 \\
Ethanol $(\% \mathrm{v} / \mathrm{v})$ & 5.0 \\
H/C ratio & 1.776 \\
O/C ratio & 0.015 \\
\hline
\end{tabular}

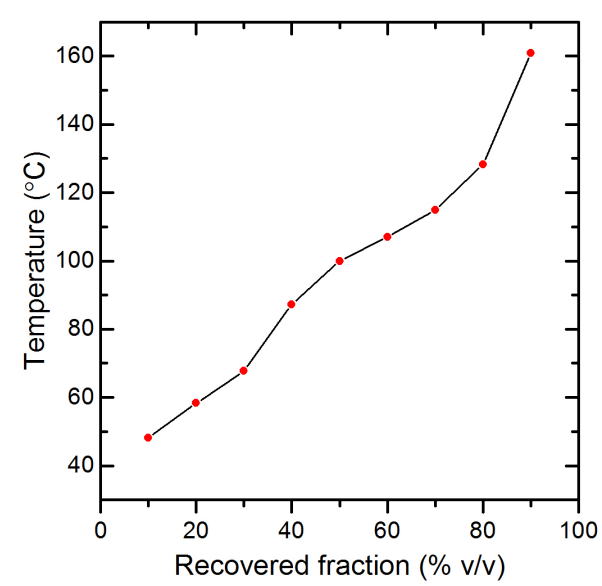

Figure 3: Measured distillation characteristics for the reference gasoline used in this study. 


\subsection{Testing Methodology}

The experimental test matrix incorporated a range of engine loads at fixed speeds of 1200 and 2000 rpm. The test conditions were monitored for 2 minutes to ensure steady-state operation had been reached (Table 3). An AVL data acquisition system was then used to acquire 12000 cycles of test data for each operating condition. The repeatability of the tests was checked by acquiring three randomized replicate measurements at different engine loads. All testing was undertaken with a clean engine. The piston was regularly cleaned of deposits to minimize any chance of deposit-induced pre-ignition. The lubricating oil was also replaced at regular intervals.

Table 3: Test conditions used in this study.

\begin{tabular}{lr}
\hline Engine speed & $1200,2000 \mathrm{rpm}$ \\
Intake air temperature & $30^{\circ} \mathrm{C}$ \\
Coolant temperature & $80^{\circ} \mathrm{C}$ \\
Oil temperature & $80{ }^{\circ} \mathrm{C}$ \\
Relative air-fuel ratio $(\lambda)$ & 1 \\
\hline
\end{tabular}

The single fuel testing on gasoline was conducted by applying the minimum spark advance for best torque (MBT). This corresponds to combustion phasing (CA50) of approximately 8 CAD aTDC, where CA50 denotes the crank angle at which $50 \%$ of the fuel mass has been burned. If the engine was knock limited, then the spark timing was retarded to achieve borderline knock. This was established using a maximum peak-to-peak knock intensity (KI) threshold of 0.5 bar. To confirm borderline knock had been established, the spark timing was marginally advanced to observe that the peak-to-peak KI then exceeded this threshold. Two set of experiments were performed at an intake pressure of approximately 1 bar, i.e. wide open throttle (WOT). The methane fraction was increased from $0 \%$ to $100 \%$, while reducing the gasoline fraction to maintain stoichiometry $(\lambda=1)$. In first case, the spark timing is held constant, while in the second case, the spark timing is swept to achieve MBT timing while operating on the different gasoline/methane mixtures.

A similar methodology was applied in the dual-fuel testing on gasoline and methane. The engine was operated exclusively on gasoline at lower loads where MBT spark timing (CA50 8 CAD aTDC) could be maintained. As the load and intake pressure were increased, the engine became knock limited, and methane $($ RON $>130)$ was added to increase the anti-knock quality of the fuel. Stoichiometric combustion $(\lambda=1)$ was maintained by reducing the gasoline fuel fraction as the methane fuel fraction was increased. This strategy enabled MBT spark timing (CA50 8 CAD aTDC) to be maintained with increasing engine load, thereby maximizing the thermal efficiency of the engine at all times. A detailed description of the dual-fuel test methodology can be found in the literature [20]. 


\section{Results and Discussion}

The results are presented in separate sections. The first two sections present mixture sweeps of varying gasoline/methane ratios (100\% gasoline to $100 \%$ methane) at wide open throttle (WOT) for both fixed and variable spark timing. The former is representative of a retrofitted gasoline engine where the calibration has not been optimized for the higher-octane methane $(\mathrm{RON}>130)$, while the latter is representative of an engine with an electronic control unit calibrated for natural gas operation. The third section presents analysis of engine load sweeps where the calibration has been optimized for varying gasoline/methane ratios (again, $100 \%$ gasoline to $100 \%$ methane). The fourth section examines the $\mathrm{CO}_{2}$-equivalent emissions to elucidate the broader environmental impact of an optimized gasoline/natural gas vehicle. Finally, the findings from the previous sections are related to the combustion knock intensity distributions.

\subsection{Duel-Fuel Mixture Sweeps at WOT with Fixed Spark Timing}

The first set of experiments were used to establish a baseline for dual-fuel operation on gasoline and methane using a non-optimized engine calibration. At wide open throttle (WOT) and $1200 \mathrm{rpm}$, the fraction of gasoline in the fuel mixture was progressively swept from $100 \%$ to $0 \%$, i.e., $0 \%$ to $100 \%$ methane (Figure 4 ). During the sweep, the pulse width of the direct injector (gasoline) and port-fuel injector (methane) were concurrently adjusted to maintain stoichiometry $(\lambda=1)$. The spark timing was held constant at 8 CAD bTDC throughout the test (Figure 4). This is intended to simulate an engine calibrated for gasoline, but operated on both gasoline/methane mixtures and pure methane, without any changes to the engine calibration.

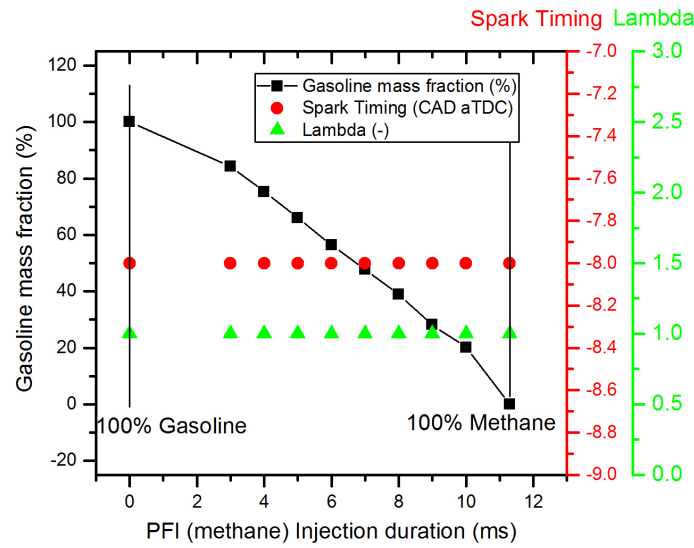

Figure 4: Gasoline fuel mass fraction, spark timing and lambda as a function of PFI (methane) injection duration at wide open throttle (WOT) and $1200 \mathrm{rpm}$. The spark timing was held constant as the PFI (methane) injection duration was progressively increased. The injection duration of the gasoline direct injector was concurrently reduced to maintain stoichiometry $(\lambda=1)$.

The indicated mean effective pressure, knock intensity, combustion phasing and combustion duration as a function of the PFI (methane) injection duration are presented in Figure 5. The initial spark timing, i.e., 
at a PFI (methane) injection duration of zero, was specified based on the octane quality of the gasoline. At wide open throttle, the combustion phasing initially corresponds to CA50 17 CAD aTDC (Figure 6c). This exceeds the typically observed value of CA50 8 CAD aTDC for maximum brake torque (MBT), thereby indicating the engine was knock limited at this condition while operating on gasoline alone. This can also be observed in the measured knock intensity (Figure 5b), which initially exceeds the threshold for borderline knock ( 0.5 bar) until octane enhancement is subsequently provided by the methane.

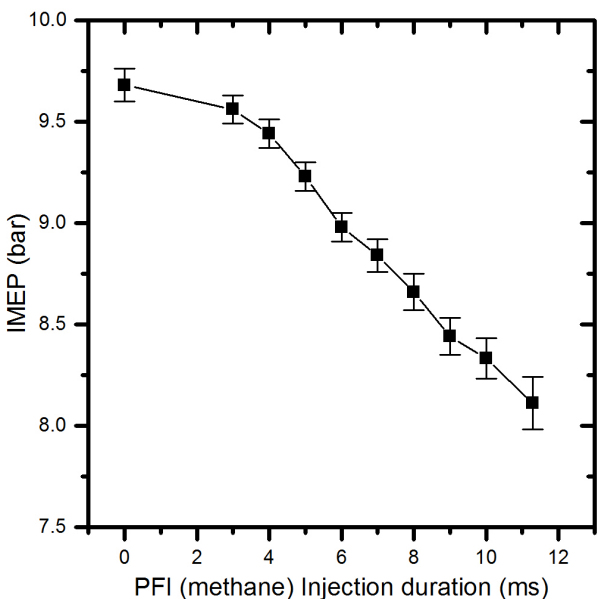

(a)

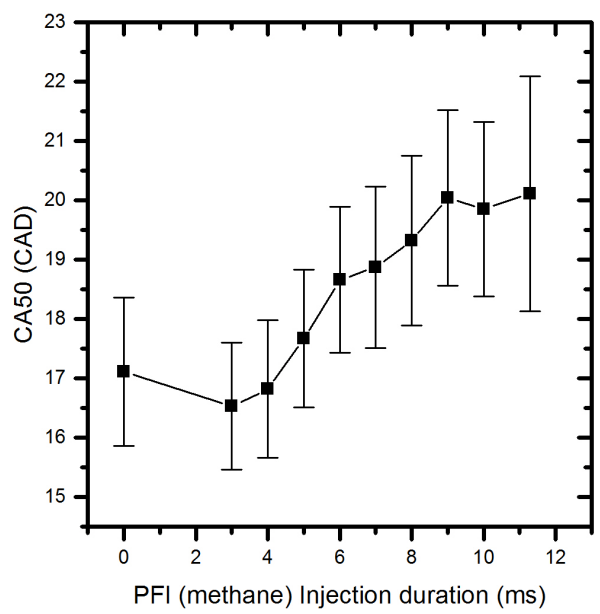

(c)

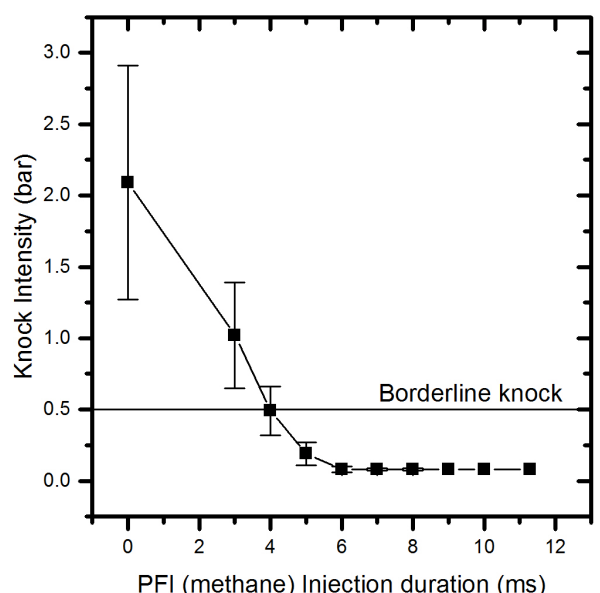

(b)

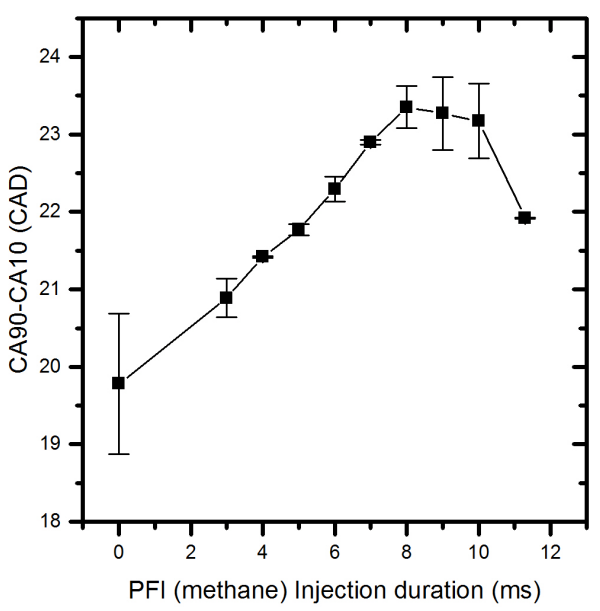

(d)

Figure 5: Indicated mean effective pressure (IMEP), knock intensity (KI), combustion phasing (CA50) and combustion duration (CA90-CA10) as a function of PFI (methane) injection duration at wide open throttle (WOT) and 1200 rpm. The spark timing was held constant as the PFI (methane) injection duration was progressively increased. The injection duration of the direct injector (gasoline) was concurrently reduced to maintain stoichiometry $(\lambda=1)$.

As the PFI (methane) injection duration is increased, the indicated mean effective pressure (IMEP) progressively decreases (Figure 5a). This is due to the gaseous methane displacing some of the intake air 
(refer to Figure 1), reducing the airflow to the engine, and consequently the torque by $16 \%$. At fixed spark timing, both the combustion phasing and combustion duration (Figures $5 \mathrm{c}$ and $5 \mathrm{~d}$, respectively) progressively increase. This is due to the lower flame speed of methane [23]. The knock intensity (Figure 6b) falls below the borderline knock threshold when the PFI (methane) injection duration exceeds approximately 4 milliseconds (corresponding to a methane fuel fraction of approximately 25\%). This indicates that octane giveaway occurs beyond this point, i.e., the higher-octane quality of the methane $(\mathrm{RON}>130)$ is not being put to use to enhance the engine torque or efficiency. This would require the spark timing to be advanced well beyond the initial limits that were specified based on the octane quality of the gasoline alone (RON 97.5). Additionally, the reduced volumetric efficiency lowers the effective work that can be extracted from the cycle.

Even though the spark timing is not optimized for the high-octane quality of the methane (RON $>130)$ at higher PFI injection durations, this has only a limited impact on the combined indicated specific fuel consumption (Figure 6) due to the higher mass-based heating value of methane. As a result, the ISFC maintains an approximately constant value of $285 \mathrm{~g} / \mathrm{kWh}$, despite the reduction in efficiency as the PFI (methane) injection duration increases. The latter is due to a combination of reduced volumetric efficiency, and a reduction in the charge burn rates (Figure 5d). The engine efficiency could be improved by either optimizing the spark timing for a given mixture ratio of gasoline to methane, or alternatively optimizing the mixture ratio of gasoline to methane for the combustion phasing that maximizes the efficiency of the engine. These scenarios are considered in the subsequent results sections.

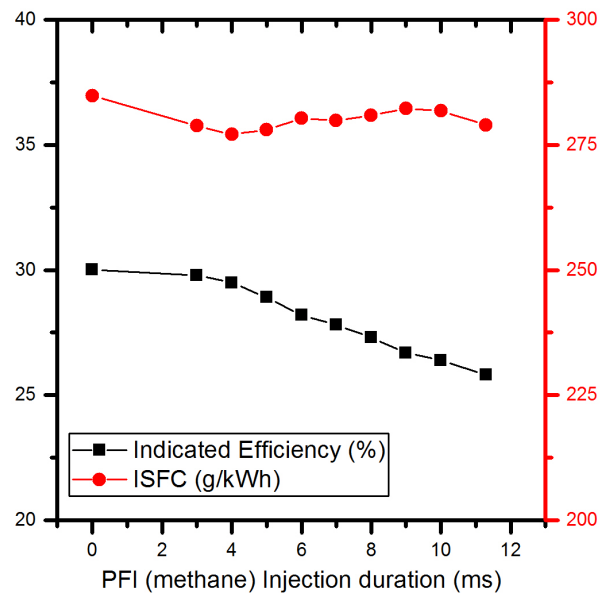

Figure 6: Indicated efficiency and combined indicated specific fuel consumption (ISFC) as a function of PFI (methane) injection duration at wide open throttle (WOT) and $1200 \mathrm{rpm}$. The spark timing was held constant as the PFI (methane) injection duration was progressively increased. The injection duration of the direct injector (gasoline) was concurrently reduced to maintain stoichiometry $(\lambda=1)$. 


\subsection{Duel-Fuel Mixture Sweeps at WOT with Optimized Spark Timing}

The second set of experiments were used to optimize the previous baseline for dual-fuel operation on gasoline and methane. At wide open throttle (WOT) and $1200 \mathrm{rpm}$, the fraction of gasoline in the fuel mixture was again progressively swept from $100 \%$ to $0 \%$, i.e. $0 \%$ to $100 \%$ methane (Figure 7 ). During the sweep, the pulse width of the direct injector (gasoline) and port-fuel injector (methane) were concurrently adjusted to maintain stoichiometry $(\lambda=1)$. But in this test case, the spark timing was adjusted as the PFI (methane) injection duration was progressively increased (Figure 7). As one can expect, with reducing gasoline fraction (black square) in Figure 7, the spark timing can be further advanced (red circle). This case is intended to simulate an engine control unit that is optimized for gasoline, gasoline/methane mixtures, as well as pure methane.

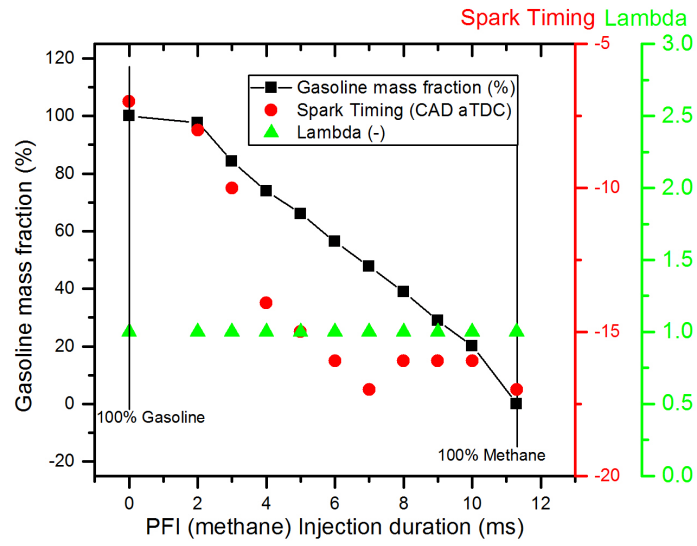

Figure 7: Gasoline fuel mass fraction, spark timing and lambda as a function of PFI (methane) injection duration at wide open throttle (WOT) and $1200 \mathrm{rpm}$. Cases are shown for both fixed spark timing and spark timing that is adjusted as the PFI (methane) injection duration was progressively increased. The injection duration of the direct injector (gasoline) was concurrently reduced to maintain stoichiometry $(\lambda=1)$.

The indicated mean effective pressure, knock intensity, combustion phasing and combustion duration as a function of the PFI (methane) injection duration are presented in Figure 8. Again, the initial spark timing, i.e. at a PFI (methane) injection duration of zero, was specified based on the octane quality of the gasoline. However, in this second test case, the spark timing was re-optimized as the PFI (methane) injection duration is increased to account for variations in the fuel properties as the gasoline/methane mixture ratio changed.

Initially, the combustion phasing (CA50 18 CAD aTDC) is again limited by the available octane quality of the gasoline (Figure 8c). However, as the PFI (methane) injection duration is progressively increased, the higher methane fuel fraction enables the spark timing to be advanced. This is accompanied by a reduction in the knock intensity (Figure 8b), thereby indicating that the additional octane appetite of the engine (due to more advanced spark timing) is more than offset by the increase in the octane quality of the fuel 


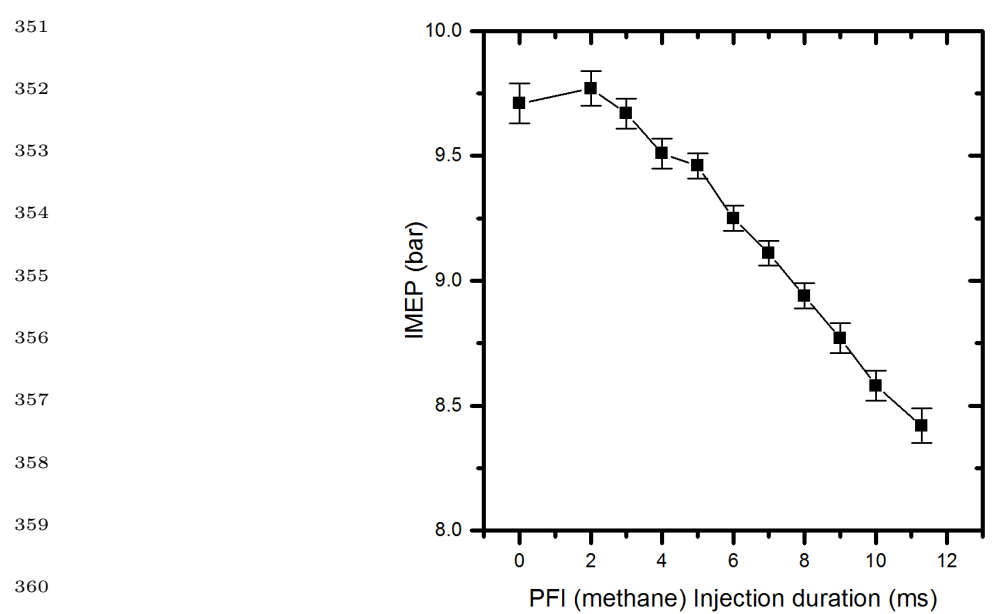

(a)

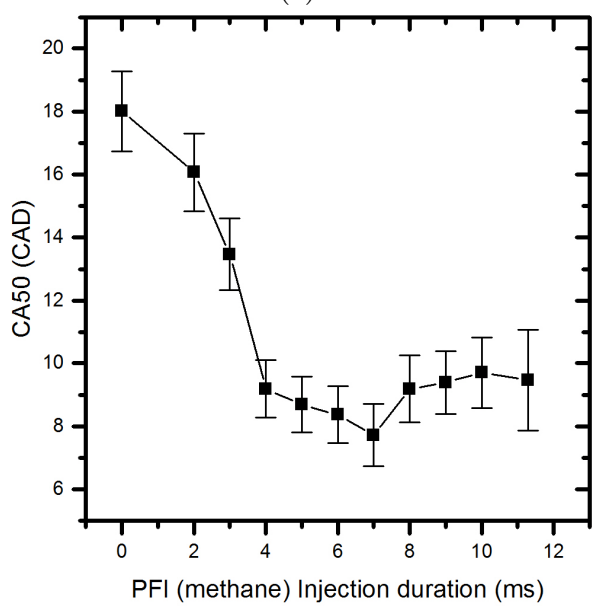

(c)

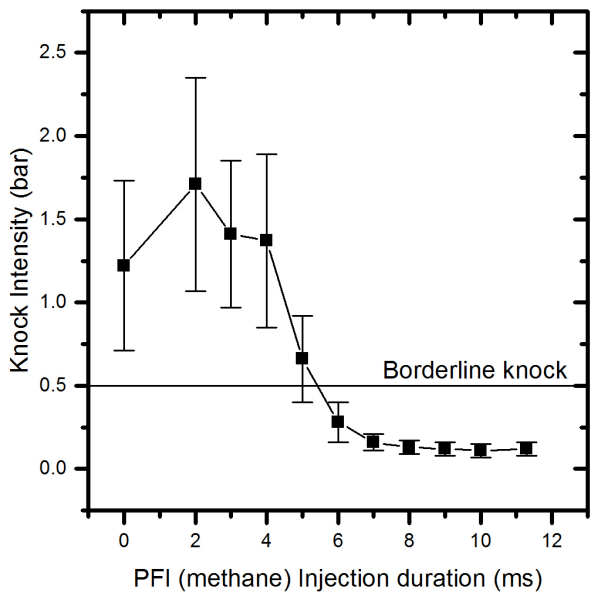

(b)

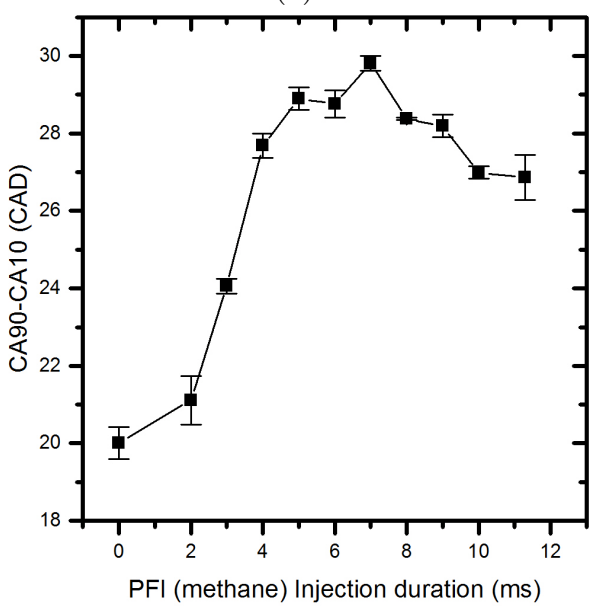

(d)

Figure 8: Indicated mean effective pressure (IMEP), knock intensity (KI), combustion phasing (CA50) and combustion duration (CA90-CA10) as a function of PFI (methane) injection duration at wide open throttle (WOT) and $1200 \mathrm{rpm}$. In this test case, the spark timing was adjusted as the PFI (methane) injection duration was progressively increased (refer to Figure 7). The injection duration of the direct injector (gasoline) was concurrently reduced to maintain stoichiometry $(\lambda=1)$.

mixture (due to the higher methane fuel fraction). The combustion phasing is observed to reach the value corresponding to maximum brake torque (CA50 8 CAD aTDC) at a PFI (methane) injection duration of approximately 5 milliseconds (corresponding to a methane fuel fraction of $45 \%$ ). Beyond this point, the knock intensity remains below the borderline knock threshold (Figure 8b), while the combustion phasing (Figure 8c) can be maintained at the value corresponding to peak engine efficiency (CA50 8 CAD aTDC). This again demonstrates that octane giveaway occurs for methane fuel fraction exceeding approximately $50 \%$, and that further methane addition does not bring about an increase in the engine efficiency (Figure 9). Indeed, the indicated efficiency decreases due to the lower volumetric efficiency with increasing methane 
utilization. This is again offset by the higher mass-based heating value of methane, enabling the ISFC to generally be maintained below approximately $270 \mathrm{~g} / \mathrm{kWh}$. As such, optimizing the spark timing for specific gasoline/methane ratios improves the ISFC by up to $5 \%$.

In general, the indicated efficiency of the second case is higher than in first case, due to optimized spark timing. However, beyond a PFI (methane) injection duration of 6 milliseconds, methane injection is not necessary and only reduces the specific power of the engine. This points to another issue with modern bi-fuel engines. Even if the engine control hardware was tuned to advance the spark timing based on methane utilization, the high-octane quality of methane would mean that the engine is not knock limited at any operating condition. The potential for higher IMEP is therefore lost. If the engine were optimized for methane-only operation, increasing the compression ratio would offset this downside. However, this is not an option for retrofitted bi-fuel engine. To this end, the next methodology could serve as a potential solution.

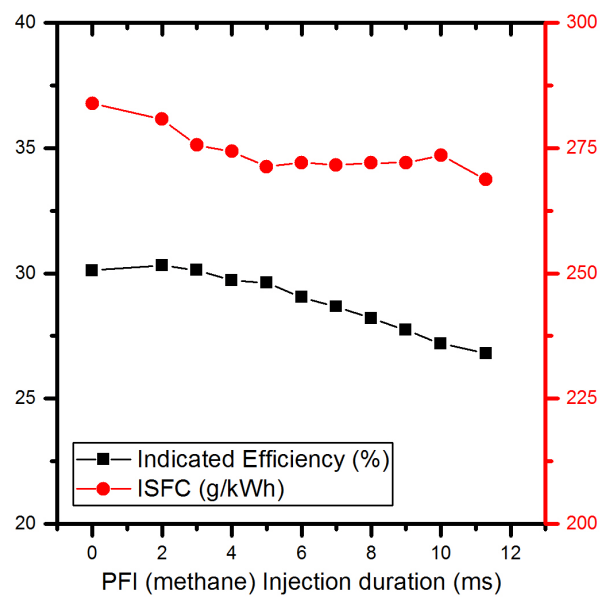

Figure 9: Indicated efficiency and combined indicated specific fuel consumption (ISFC) as a function of PFI (methane) injection duration at wide open throttle (WOT) and $1200 \mathrm{rpm}$. Data is shown for both fixed spark timing as well as spark timing that was adjusted as the PFI (methane) injection duration was progressively increased. The injection duration of the direct injector (gasoline) was concurrently reduced to maintain stoichiometry $(\lambda=1)$.

\subsection{Optimized Dual-Fuel Engine Calibration for Peak Efficiency}

The third set of experiments were used to explore an optimized dual-fuel calibration over a wide range of engine loads. The engine was initially operated at wide open throttle and $2000 \mathrm{rpm}$. This speed is higher than the previous tests, and therefore the engine is less knock limited. As a result, the engine could initially be operated at maximum brake torque and peak efficiency (CA50 8 CAD aTDC) on gasoline alone, without exceeding the borderline knock threshold of 0.5 bar (Figure 10). The intake boost pressure was subsequently increased, while maintaining stoichiometry $(\lambda=1)$ by increasing the DI (gasoline) injection duration. This 
caused the engine to become knock limited ( $\mathrm{KI}>0.5$ bar). Instead of retarding the combustion phasing, the methane fraction was increased and the gasoline fuel fraction was reduced until the knock intensity fell below the 0.5 bar borderline knock threshold (Figures 10b and 10c, respectively). Stoichiometry $(\lambda=1)$ was maintained at all times (Figure 10d).

The intake pressure was again increased in increments of 0.05 bar, and observations are made at stoichiometric operation corresponding to gasoline addition (black circles in Figure 10b). This condition exhibits higher knock intensity, and then by replacing some of the gasoline with just the minimum amount of methane, the knock intensity can once again be brought down to the 0.5 bar threshold (Figure 10c). In this way, there are two observations made at each intake pressure. Firstly, a high knock intensity condition with gasoline addition used to maintain stoichiometry with increasing intake boost pressure. And secondly, the exact amount of methane addition replacing gasoline, while yielding a knock intensity of 0.5 bar. This calibration strategy enabled peak efficiency (CA50 $~ 8 \mathrm{CAD}$ aTDC) to be maintained with increasing engine load, without exceeding the 0.5 bar borderline knock threshold. The corresponding methane fuel mass fraction as a function of engine load, and the fraction of stoichiometry obtained from methane are presented in Figure 11.

Selected in-cylinder pressure traces for the optimized dual-fuel calibration strategy are presented in Figure 12. These exhibit unconventional features for a spark-ignition engine being operated at very high loads. In particular, the location of the peak in-cylinder pressure remains constant with increasing intake boost levels (and consequently engine load). Ordinarily, the combustion phasing must be retarded in a singlefuel gasoline engine to avoid knock. This leads to a reduction in the expansion ratio, and consequently a reduction in engine efficiency.

\subsubsection{Efficiency and Specific Fuel Consumption}

The indicated efficiency, indicated specific fuel consumption (ISFC), volumetric efficiency and combustion efficiency for the optimized dual-fuel calibration strategy are presented in Figure 13. For comparative purposes, selected data is presented at equivalent conditions for the engine operated on gasoline. The indicated efficiency for the optimized dual-fuel calibration strategy has a peak value of approximately $36 \%$. The peak value can largely be maintained across the full range of engine loads, with the indicated efficiency still exceeding $33 \%$ at an engine load of 32 bar. The marginal reduction in indicated efficiency with increasing methane utilization is due to the reduced volumetric efficiency (Figure 13b), rather than the normal deterioration in combustion phasing observed in single-fuel gasoline engines at higher loads, i.e., combustion phasing of CA50 8 CAD aTDC was maintained throughout these tests (Figure 10a). This reduced volumetric efficiency is caused by gaseous methane displacing an increasingly large amount of intake air as the load is increased. As an example, a $10 \%$ reduction in volumetric efficiency would be observed for stoichiometric $(\lambda=1)$ operation on methane, with respect to gasoline (refer to Figure 1). A further contributor to the reduced indicated efficiency is the slower charge burns rates from the lower flame speed of methane with 


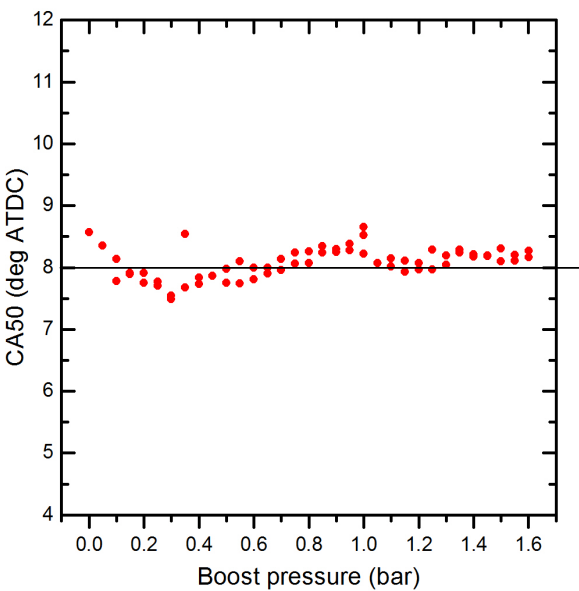

(a)

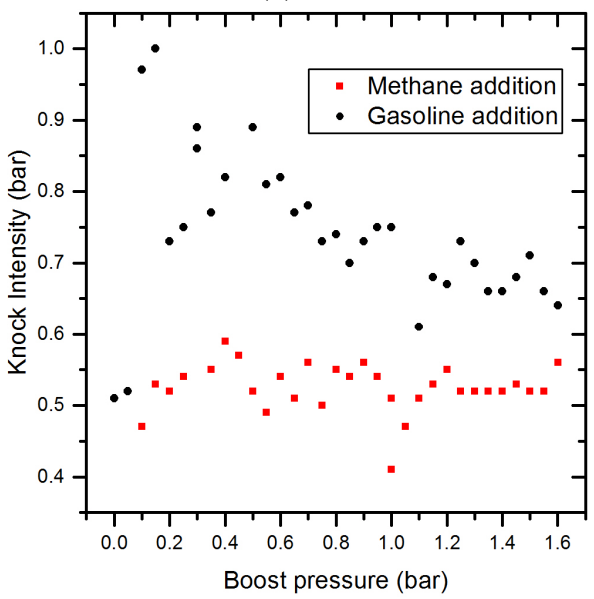

(c)

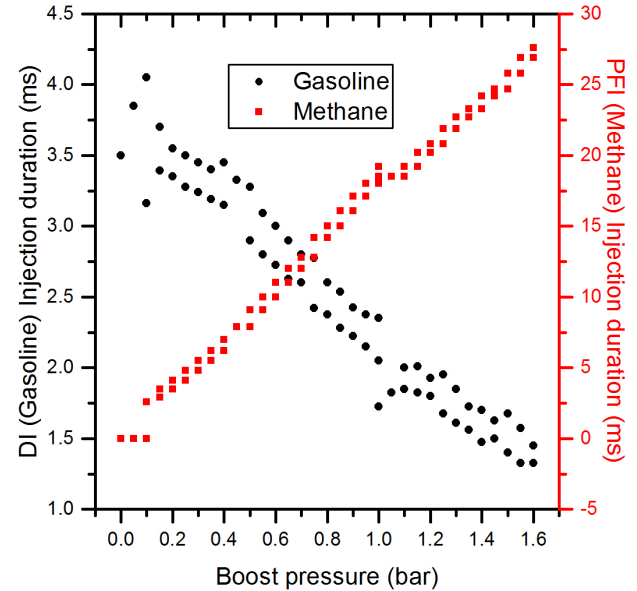

(b)

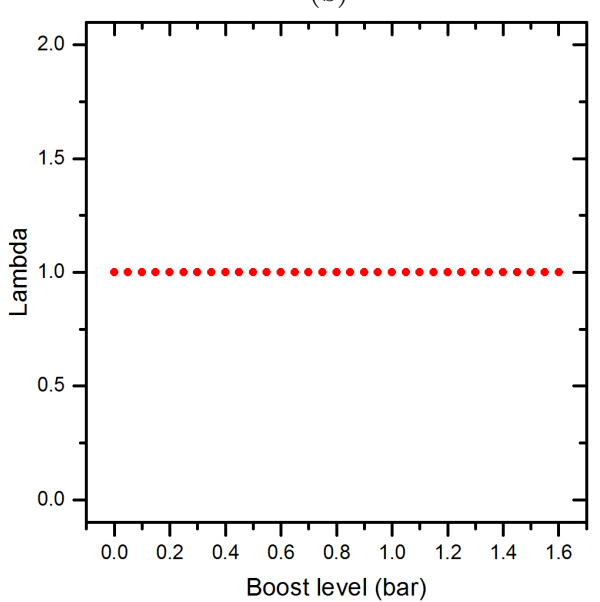

(d)

Figure 10: Combustion phasing (CA50), PFI (methane) and DI (gasoline) injection durations, knock intensity (KI) and lambda $(\lambda)$ as a function of intake boost pressure at $2000 \mathrm{rpm}$. Instead of retarding the combustion phasing when the engine became knock limited, the methane fraction was increased and the gasoline fuel fraction was reduced until the knock intensity fell below the borderline knock threshold. Stoichiometry $(\lambda=1)$ was maintained at all times. The intake boost level was increased in 0.05 bar increments.

respect to gasoline (refer to Figures $5 \mathrm{~d}$ and $8 \mathrm{~d}$ ). A slower burn rate means the same combustion phasing (CA50) will result in a lower indicated mean effective pressure (IMEP).

Similar to the in-cylinder pressure traces presented previously in Figure 12, the ISFC exhibits unconventional features for a spark-ignition engine. This results from a combination of two different factors. Firstly, the engine efficiency at high load is considerably higher than a conventional spark-ignition engine, since the optimal combustion phasing (CA50 8 CAD aTDC) enables the expansion ratio to be maximized. And secondly, the mass-based heating value of methane is higher than gasoline. Collectively, these two factors result in the ISFC attaining its minimum value of approximately $221 \mathrm{~g} / \mathrm{kWh}$ at the highest engine load of 


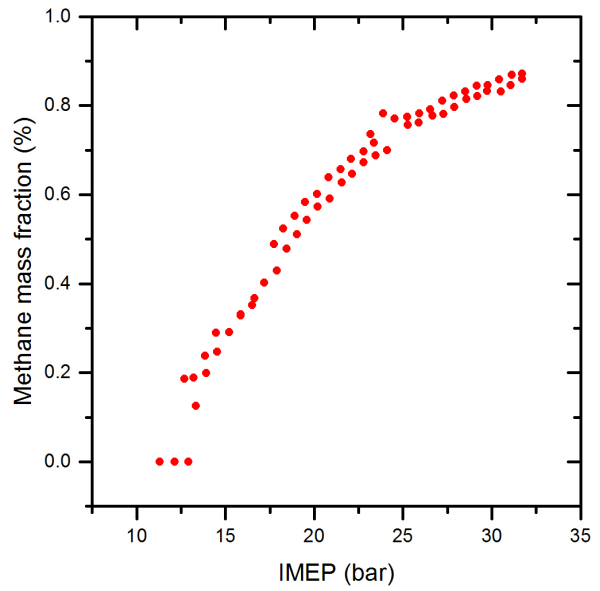

(a)

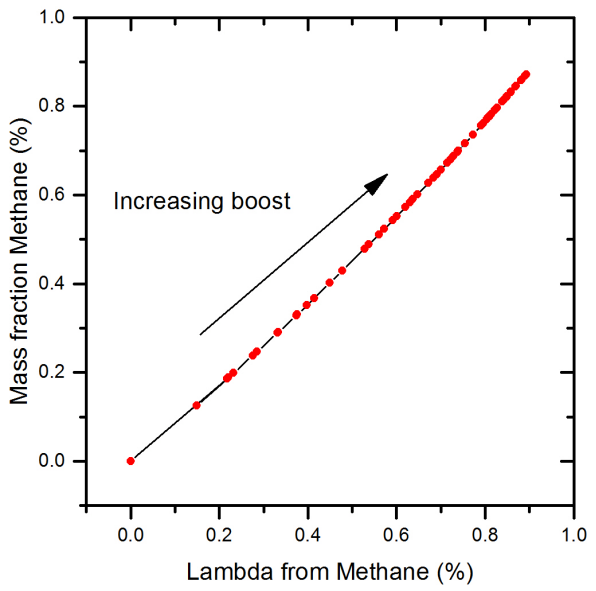

(b)

Figure 11: Methane fuel mass fraction as a function of engine load, along with the fraction of stoichiometry obtained from methane at $2000 \mathrm{rpm}$. Instead of retarding the combustion phasing when the engine became knock limited, the methane fraction was increased and the gasoline fuel fraction was reduced until the knock intensity fell below the borderline knock threshold. The intake boost level was increased in 0.05 bar increments.

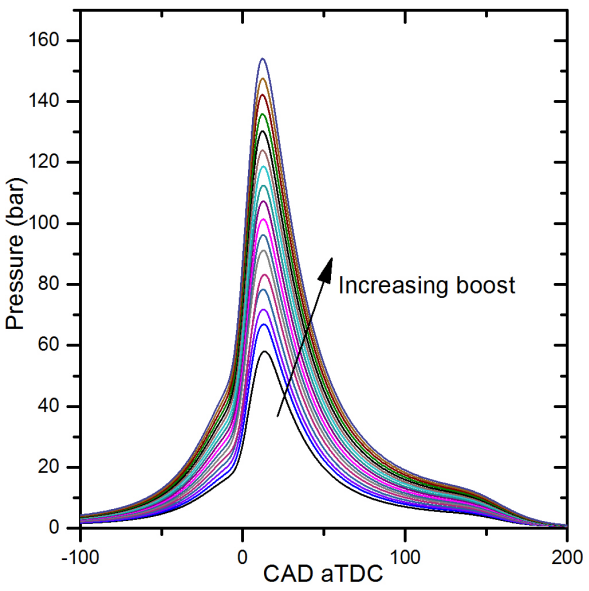

Figure 12: In-cylinder pressure for different engine loads at $2000 \mathrm{rpm}$. The curves correspond to intake boost levels of approximately 1.0 to 2.6 bar absolute. The upper value corresponds to an indicated mean effective pressure (IMEP) of approximately 32 bar.

32 bar. Further, the ISFC for the optimized dual-fuel calibration strategy is always considerably lower than the single-fuel gasoline baseline at the equivalent engine load. Combustion efficiency is a small contributor towards the observed differences (Figure 13b).

\subsubsection{Engine Emissions}

The carbon monoxide $(\mathrm{CO})$, nitrogen oxides $\left(\mathrm{NO}_{X}\right)$, non-methane hydrocarbons (NMHC), carbon dioxide $\left(\mathrm{CO}_{2}\right)$ and methane $\left(\mathrm{CH}_{4}\right)$ emissions as a function of engine load are presented in Figure 14. Although 


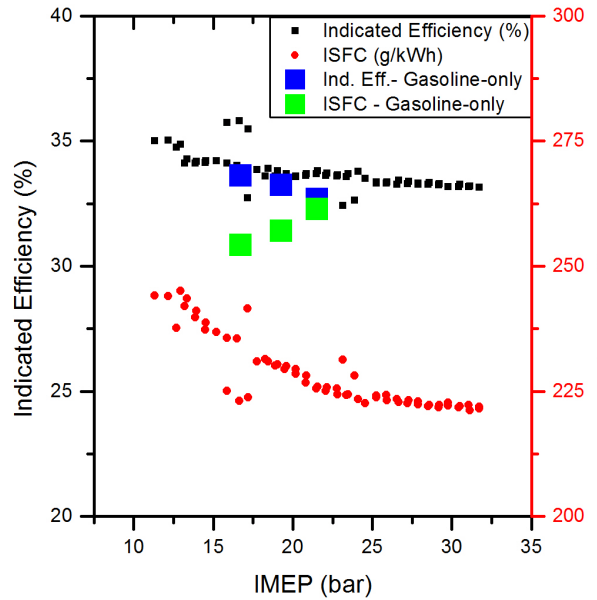

(a)

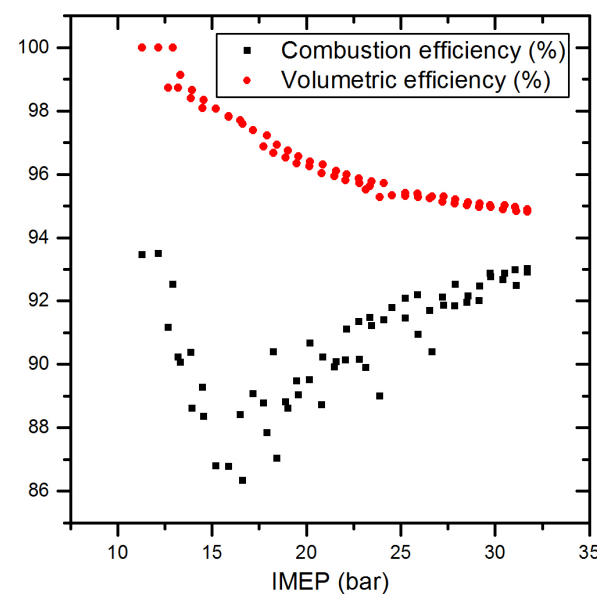

(b)

Figure 13: Indicated specific fuel consumption (ISFC), indicated efficiency, volumetric efficiency and combustion efficiency as a function of engine load at $2000 \mathrm{rpm}$. The combustion phasing was maintained at the value corresponding to peak efficiency (CA50 8 CAD aTDC) with increasing engine load, while maintaining borderline knock (KI <0.5 bar). For comparative purposes, selected data is presented at equivalent conditions for the engine operated on gasoline. In this case, the combustion phasing must be heavily retarded (CA50 >15 CAD aTDC) to maintain the knock intensity close to the borderline knock threshold (KI <0.5 bar).

the $\mathrm{NO}_{X}$ emissions are approximately constant, the $\mathrm{CO}$ and $\mathrm{NMHC}$ emissions decrease with increasing engine load (Figure 14a). This is directionally consistent with higher rates of methane utilization, and most likely improved air-fuel mixture formation [24]. The in-cylinder pressures and temperatures also increase with engine load, promoting further oxidation of any NMHC emissions. Similarly, the reduced potential for liquid fuel impingement with increasing gaseous fuel utilization [25] would also be expected to result in lower CO emissions.

The $\mathrm{CO}_{2}$ and $\mathrm{CH}_{4}$ emissions exhibit strongly contrasting trends (Figure 14b). While the $\mathrm{CO}_{2}$ emissions decrease with increasing engine load, the $\mathrm{CH}_{4}$ emissions increase by almost an order of magnitude between approximately 12 and 32 bar. The reduced $\mathrm{CO}_{2}$ emissions can be directly attributed to the higher average fuel $\mathrm{H} / \mathrm{C}$ ratio of the fuel with increasing methane utilization. However, greater methane utilization also coincides with higher $\mathrm{CH}_{4}$ emissions due to incomplete combustion, and the air-fuel mixture short-circuiting the combustion chamber during scavenging.

Although the $\mathrm{CH}_{4}$ emissions are comparatively small, the Global Warming Potential (GWP) of this greenhouse gas is 25 times stronger than $\mathrm{CO}_{2}$ when considered based on a 100 year time frame [26]. As a result, some of the benefits associated with increased methane utilization can be offset by the increased $\mathrm{CH}_{4}$ emissions. This can be observed in the $\mathrm{CO}_{2}$-equivalent $\left(\mathrm{CO}_{2}\right.$-e) emissions presented in Figure 15 , which attain a minimum value of approximately $750 \mathrm{~g} / \mathrm{kWh}$ at an engine load of $17 \mathrm{bar}$. This is still $20 \%$ higher than the minimum value attained for the $\mathrm{CO}_{2}$ emissions in Figure $14 \mathrm{~b}(620 \mathrm{~g} / \mathrm{kWh})$. Nevertheless, the 


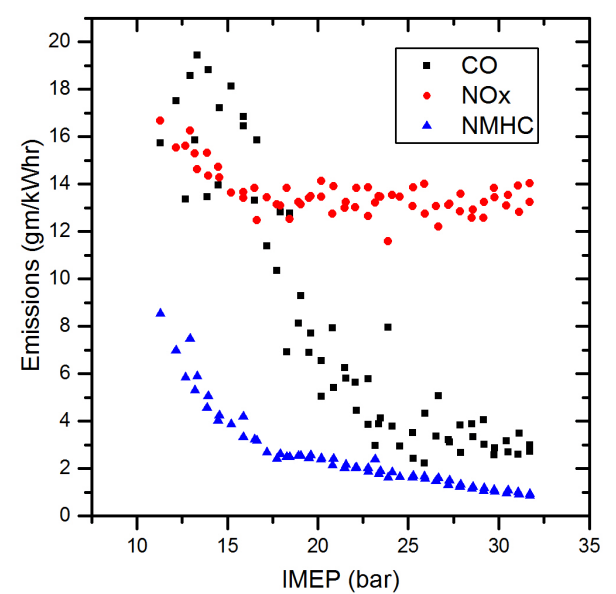

(a)

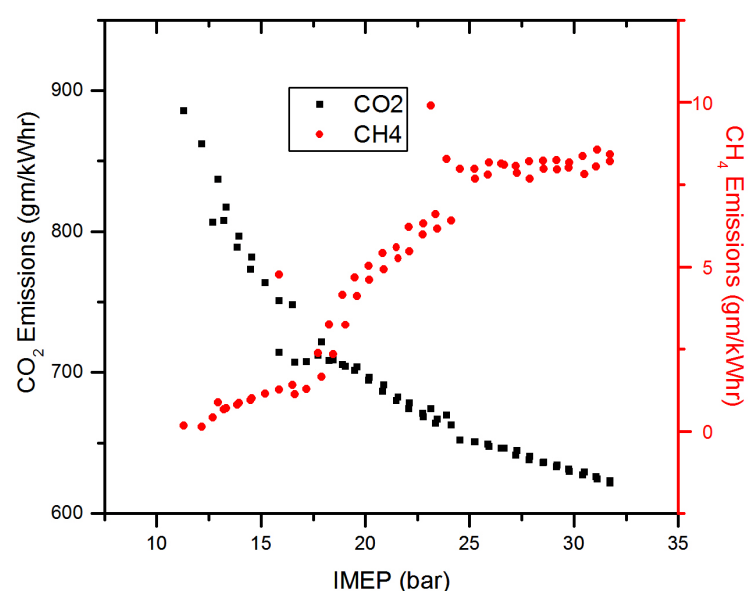

(b)

Figure 14: Carbon monoxide $(\mathrm{CO})$, nitrogen oxides $\left(\mathrm{NO}_{X}\right)$, non-methane hydrocarbons $(\mathrm{NMHC})$, carbon dioxide $(\mathrm{CO})_{2}$ and methane $\left(\mathrm{CH}_{4}\right)$ emissions as a function of engine load at $2000 \mathrm{rpm}$. The combustion phasing was maintained at the value corresponding to peak efficiency (CA50 8 CAD aTDC) with increasing engine load, while maintaining borderline knock (KI $<0.5$ bar $)$.

$\mathrm{CO}_{2}$-e emissions remain below $850 \mathrm{~g} / \mathrm{kWh}$ up to the maximum engine load of 32 bar. This suggests that an optimal gasoline/methane ratio exists for minimizing the cumulative environmental impact.

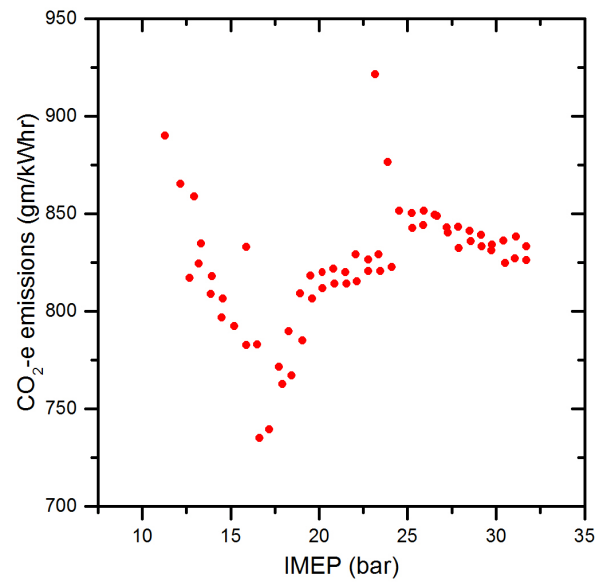

Figure 15: Carbon dioxide equivalent $\left(\mathrm{CO}_{2}\right.$-e $)$ emissions as a function of engine load at $2000 \mathrm{rpm}$. The $\mathrm{CO}_{2}$-e emissions are computed based on a Global Warming Potential (GWP) of 25 for $\mathrm{CH}_{4}$, which assumes a 100 year time frame.

\subsection{Knock Analysis}

The knock intensity distribution for different gasoline/methane ratios at wide open throttle (WOT) and $1200 \mathrm{rpm}$ (Case 1) is presented in Figure 16. The distributions are presented for different gasoline/methane 
ratios, including $100 \%$ gasoline through to $66 \%$ gasoline by mass. The spark timing was held constant as the methane fuel fraction was progressively increased.

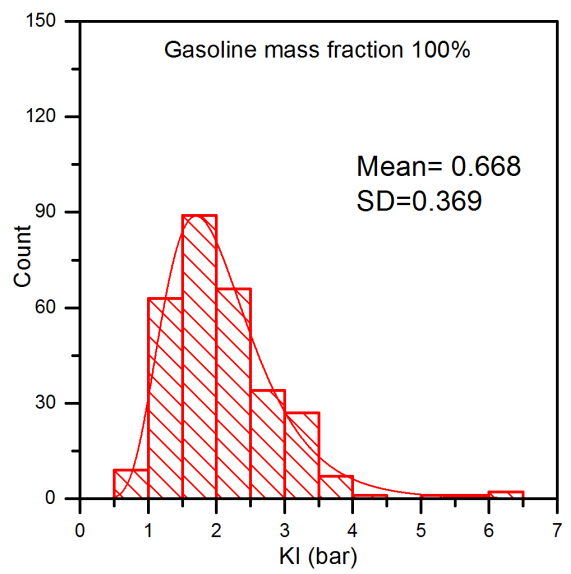

(a)

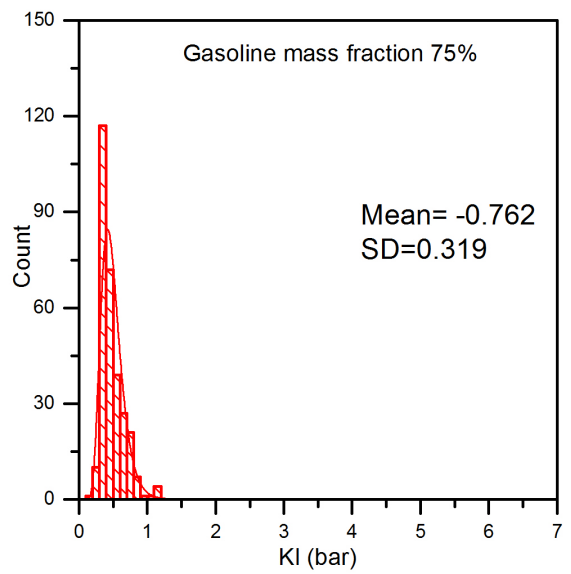

(c)

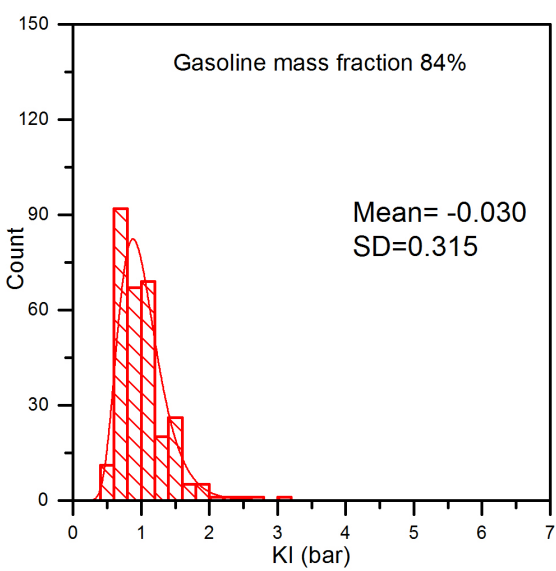

(b)

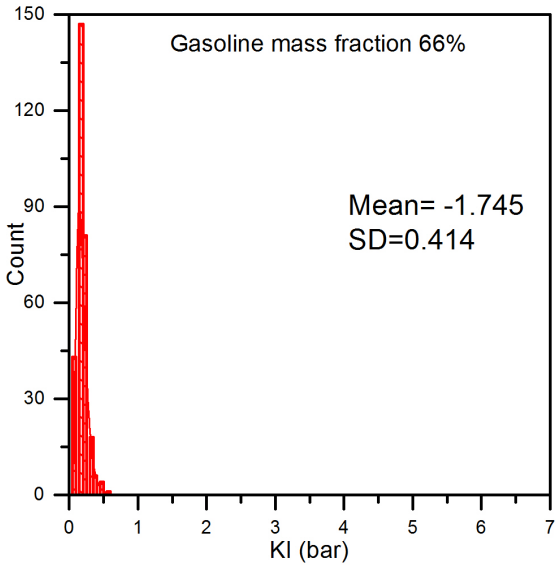

(d)

Figure 16: Knock intensity distribution for different gasoline/methane ratios at wide open throttle (WOT) and $1200 \mathrm{rpm}$ (Case 1). The spark timing was held constant as the methane fuel fraction was progressively increased. The gasoline fuel fraction was concurrently reduced to maintain stoichiometry $(\lambda=1)$.

Consistent with previous research on combustion knock with a range of engines and fuels [27-29], the knock intensity can be well characterized by a log-normal distribution. The location of the mean as well as the spread of the log-normal distribution ultimately depend on several factors. In this case, a higher methane fuel fraction coincides with a lower mean value. Additionally, the knock intensity distribution becomes narrower as the methane fuel fraction is increased. This is consistent with previous findings, which associate autoignition with temperature and mixture gradients in the end-gas [30]. Greater utilization of gaseous methane would be expected to result in a more homogeneous mixture, which likely explains the smaller scatter in the knock intensity distribution as the gasoline fuel fraction is reduced. 
Figure 17 presents the knock intensity distribution for the same engine operating condition (wide open throttle and $1200 \mathrm{rpm}$ ), but this time with the spark timing varied as the methane fuel fraction was progressively increased (Case 2). The distributions are presented for different gasoline/methane ratios, including $100 \%$ gasoline through to $56 \%$ gasoline by mass. Again, the data is well characterized by the log-normal distribution. The knock intensity distribution is centered around similar values for first three operating points as Case 1 (Figure 16), despite the spark timing being varied. However, as the methane fuel fraction is further increased, the distribution becomes progressively narrower, i.e., most of the engine cycles exhibit very low knock intensity. This is consistent with occurrence of octane giveaway, whereby the octane quality of the fuel mixture is higher than that required by the engine at this particular operating condition.

Figure 18 presents the knock intensity distribution for the optimized dual-fuel calibration strategy (Case 3) as a function of engine load. The data corresponds to the set of operating points where the knock intensity was below the borderline knock threshold of 0.5 bar (red squares in Figure 10c). This enables the distributions to be compared assuming the mean value is approximately constant. As such, any variation in the knock distribution can be attributed only to the change in the fuel composition with increasing engine load.

It can be observed that the scatter of the knock intensity distribution reduces as the methane fuel fraction is increased. The previous two cases (Figures 16 and 17) showed a reduction in the peak knock value, in addition to this same scatter. While in this case, the mean value of knock intensity is almost constant. As discussed previously, greater utilization of gaseous methane is likely to provide a more homogeneous mixture. This results in lower in-cylinder mixture gradients, and therefore lower thermal and charge stratification as the fraction of the gaseous fuel in the total mixture becomes progressively larger.

\section{Challenges and Opportunities}

This work demonstrated that a dual-fuel gasoline/natural gas vehicle may provide a range of social, economic and environmental benefits. Among these, the concept shows strong potential for higher engine efficiency, reduced vehicle fuel consumption, and reduced $\mathrm{CO}_{2}$-e emissions. However, these benefits would be contingent upon using more advanced control systems which enable the vehicle to be operated on optimal mixtures of gasoline and natural gas at different operating conditions. This may add both cost and complexity to the vehicle, particularly if such systems were retro-fitted to older vehicles.

As opposed to a dual-fuel operation, which simultaneously uses gasoline/natural gas mixtures to achieve stoichiometric operation, a bi-fuel engine operates on natural gas alone, apart from engine starting and warm up. An engine calibration tuned for gasoline operation will lead to lower specific fuel consumption, but the efficiency and IMEP will also be lower when operated on natural gas. Even if the engine had a feedback controlled calibration, it would still suffer from octane-giveaway and lower IMEP when operated 


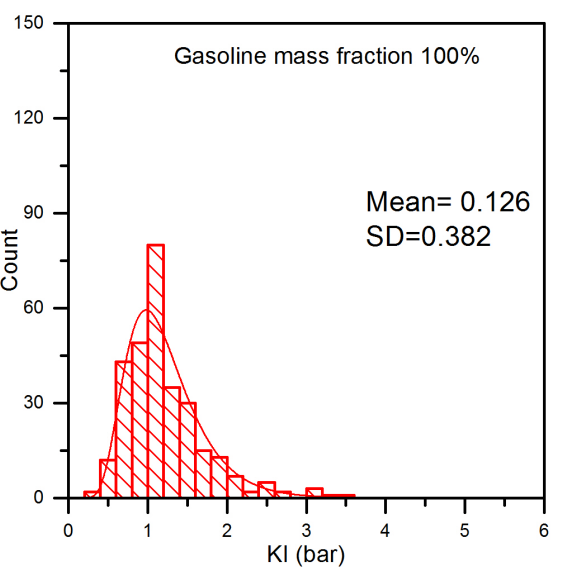

(a)

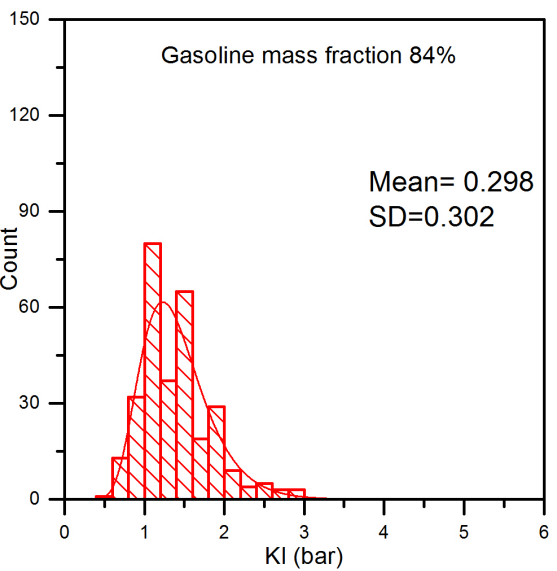

(c)

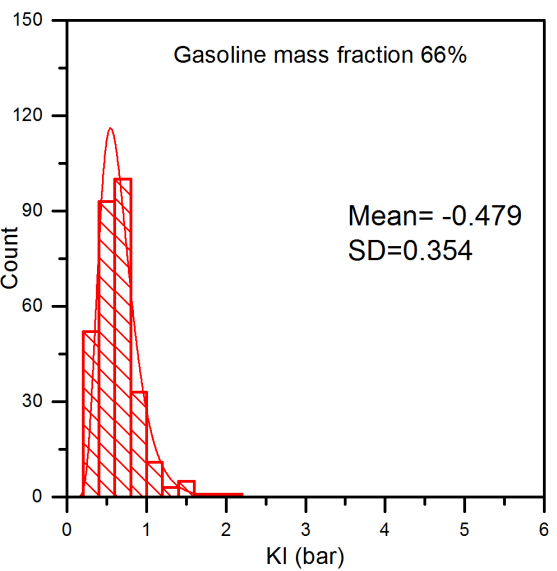

(e)

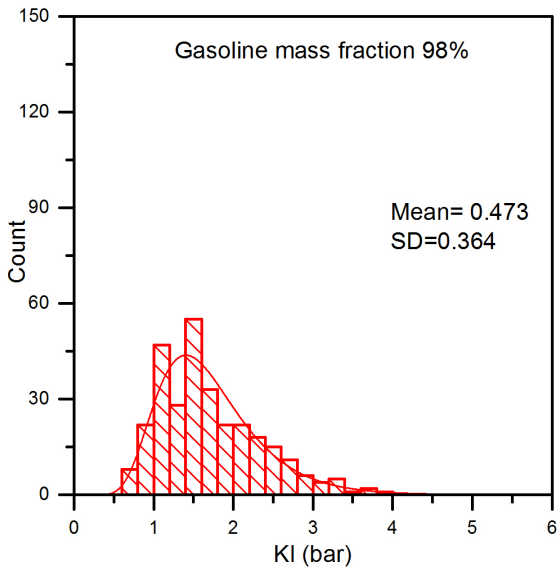

(b)

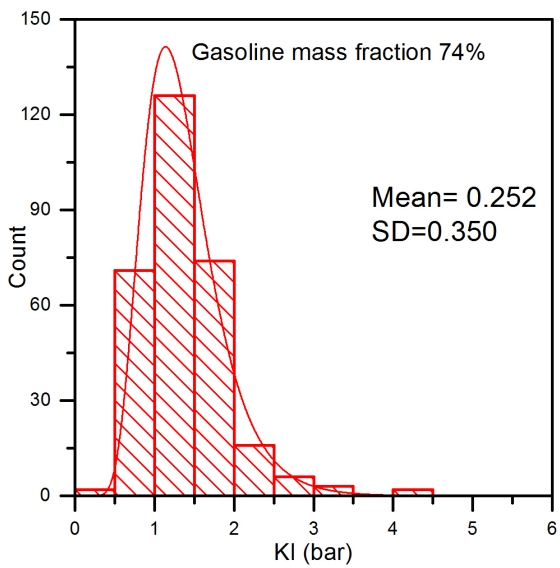

(d)

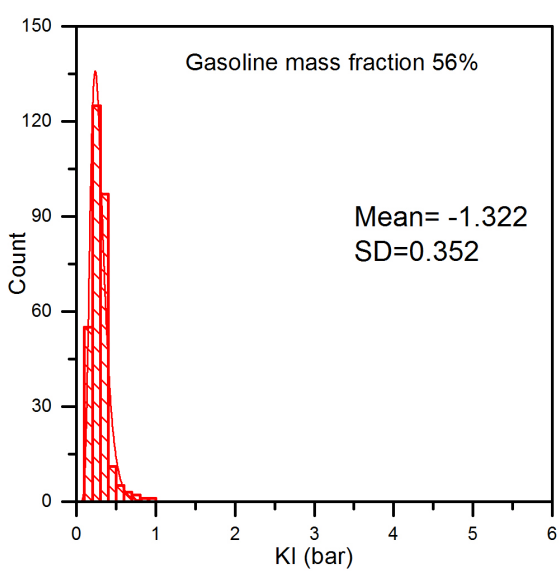

(f)

Figure 17: Knock intensity distribution for different gasoline/methane ratios at wide open throttle (WOT) and $1200 \mathrm{rpm}$ (Case 2). In this test case, the spark timing was adjusted as the methane fuel fraction was progressively increased (refer to Figure 7). The gasoline fuel fraction was concurrently reduced to maintain stoichiometry $(\lambda=1)$. 


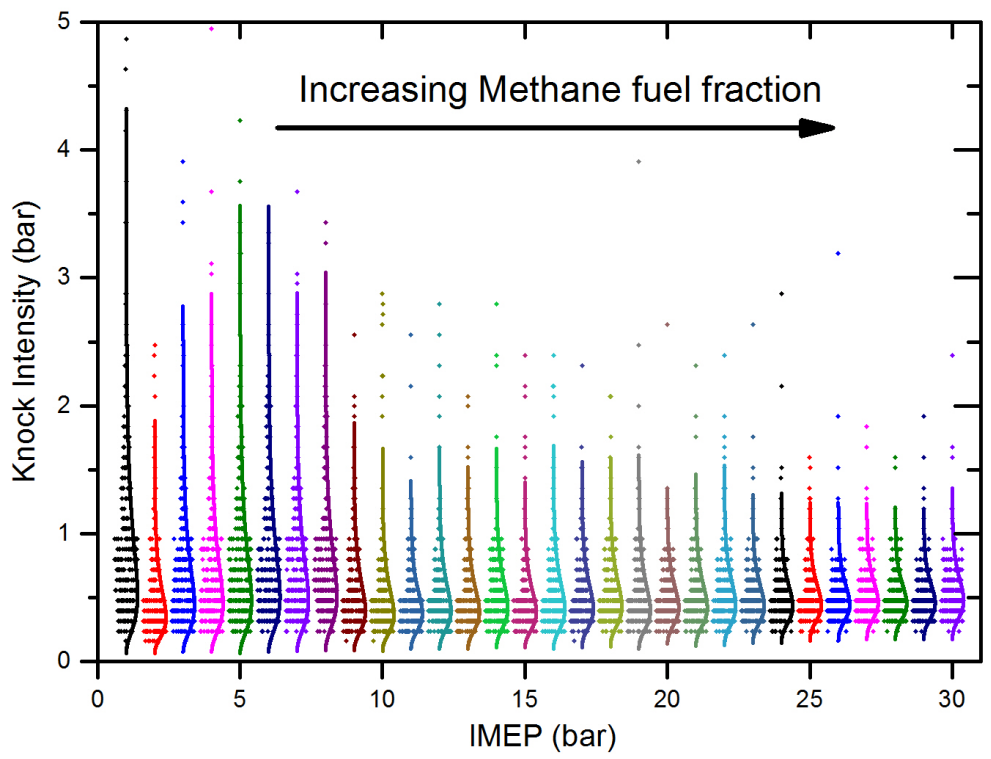

Figure 18: Knock intensity distribution as a function of engine load for different gasoline/methane ratios at $2000 \mathrm{rpm}$ (Case 3). Instead of retarding the combustion phasing when the engine became knock limited, the methane fraction was increased and the gasoline fuel fraction was reduced until the knock intensity fell below the borderline knock threshold. Stoichiometry $(\lambda=1)$ was maintained at all times.

on natural gas. The lower compression ratio, which is optimized for gasoline operation, also means the maximum benefit cannot be realized when using natural gas in a bi-fuel engine. A dual-fuel system can address these areas since it allows a lower natural gas fraction to be used. This maximizes engine efficiency and minimizes the compromises associated with the reduced volumetric efficiency, and the slower charge burn rates of natural gas.

With the recent shift towards engine downsizing and downspeeding, more engines are turbocharged than ever before. This presents a new opportunity for dual-fuel systems because engines are more knock limited at higher intake pressures. As a result, a calibrated engine can reach extremely high specific powers, while maintaining peak efficiency. However, this would require feedback-controlled fuel injection. Traditional engine control systems determine the fuel injection duration using inputs from the lambda sensor. The spark timing is established based on predefined maps and feedback from knock sensors. The strategy employed in this study instead uses methane to displace gasoline for knock control, rather than retarding the spark timing. Although this adds another control variable, it also enables peak efficiency to be maintained at higher engine loads.

Turbocharged engines often suffer from highly stochastic pre-ignition and superknock, which can lead to catastrophic engine failure [14]. Fuel-oil droplets can be a precursor for pre-ignition [31]. Such droplets can be formed by liquid fuel impinging on the cylinder liner, and diluting the lubricating oil. Previous studies have demonstrated that gaseous fuels offer higher resistance to pre-ignition $[25,32]$. In the current study, 
by increasing the gaseous fuel fraction (methane) and reducing the liquid fuel fraction (gasoline), the engine could be operated at loads as high as 32 bar IMEP without pre-ignition. This phenomena is most likely to occur at higher engine loads - the region of the engine map where greater methane fuel fractions are already required to deal with conventional engine knock. As the tendency for pre-ignition increases (with increasing intake pressure), the liquid fuel is proportionately reduced, thereby reducing the likelihood of liquid fuel impingement and oil dilution. The dual-fuel gasoline/natural gas concept could therefore increase efficiency by enabling the engine to operate at loads beyond those that are possible on gasoline alone, while maintaining a lower likelihood of experiencing abnormal combustion.

Finally, the dual-fuel gasoline/natural gas concept enabled the combustion phasing to be maintained close to peak efficiency (CA50 8 CAD aTDC) despite the engine load increasing to very high values ( $>30$ bar). This eliminates the need for high load fuel enrichment, which is utilized in single-fuel spark-ignition engines to prevent excessive thermal stresses in a range of engine components. Eliminating fuel enrichment would be particularly beneficial in the recently introduced Real Driving Emissions (RDE) test [33]. This test aims to confirm that vehicles deliver low emissions in both laboratory tests (where fuel enrichment is generally not required) and during on-road-testing on public roads (where fuel enrichment is regularly required). Although Europe is the first region to introduce these tests, it is plausible that similar tests may be introduced in other regions in the future. This may present challenges for single-fuel spark-ignition engines which depend on fuel enrichment for durability purposes.

Overall, dual-fuel operation allows:

- Improved utilization of the gaseous fuel (minimizing the compromises associated with reduced volumetric efficiency, and slower charge burn rates),

- Higher load operation at peak efficiency (since the engine is not limited by pre-ignition), and

- Stoichiometric operation at previously knock-limited conditions, thereby allowing the three-way-catalyst to operate with high conversion efficiencies at all operating conditions.

\section{Conclusions}

This paper examined the potential leveraging effect of natural gas on the performance, efficiency and broader environmental impact of a high specific output gasoline engine. Firstly, mixture sweeps were presented for varying gasoline/methane ratios (100\% gasoline to $100 \%$ methane) at wide open throttle (WOT) with both fixed and variable spark timing. This baseline information was then used to optimize the engine calibration for varying gasoline/methane ratios over a wider range of operating conditions. This was achieved by eliminating octane giveaway at low engine loads, and expanding the knock-limited performance 
envelope of the engine at higher loads. Finally, the $\mathrm{CO}_{2}$-equivalent emissions were computed to elucidate the broader environmental impact of an optimized gasoline/natural gas vehicle. The key findings were as follows:

- An engine calibrated for gasoline but operated on varying gasoline/methane mixtures without adjusting the spark timing provided few tangible benefits. As methane utilization increased, the indicated mean effective pressure (IMEP) and burn duration deteriorated due to reduced volumetric efficiency and the lower flame speed of methane, respectively. However, this only had a minor impact on the indicated specific fuel consumption (ISFC) due to the higher mass-based heating value of methane.

- Optimizing the spark timing for specific gasoline/methane mixture ratios improved the ISFC by up to $5 \%$. However, the high-octane quality of methane still could not always be fully leveraged. At WOT, methane fuel mass fractions greater than $45 \%$ resulted in octane giveaway.

- Optimizing the gasoline/methane mixture ratio to enable continuous engine operation at peak efficiency (CA50 8 CAD aTDC) with increasing engine load provided a range of benefits. Indicated efficiency could be maintained approximately constant from 12 to 32 bar, while the ISFC attained its minimum value at the highest engine load (32 bar). At intermediate loads (16 to 22 bar), the ISFC was also considerably lower than gasoline only operation.

- Although the nitrogen oxides $\left(\mathrm{NO}_{X}\right)$ emissions were constant with increasing engine load, the carbon monoxide (CO), and non-methane hydrocarbons (NMHC) decreased.

- While the carbon dioxide $\left(\mathrm{CO}_{2}\right)$ emissions decreased with engine load, the methane $\left(\mathrm{CH}_{4}\right)$ emissions increased by almost an order of magnitude between approximately 12 and 32 bar. Due to the higher Global Warming Potential (GWP) of methane, the $\mathrm{CO}_{2}$-equivalent $\left(\mathrm{CO}_{2}\right.$-e) emissions could be as much as $20 \%$ higher than the $\mathrm{CO}_{2}$ emissions. This negated some of the benefits of utilizing gasoline/methane mixtures.

- Greater utilization of gaseous methane resulted in lower in-cylinder mixture gradients (temperature and composition). This resulted in narrower distributions of knock intensity.

- This study suggests that more advanced control systems which enable vehicles to use both gasoline and natural gas simultaneously may provide a range of social, economic and environmental benefits.

\section{Acknowledgments}

The authors acknowledge funding from the Clean Combustion Research Center at King Abdullah University of Science and Technology. The authors also wish to thank Nimal Naser for enlightening discussions on the project, and the technical support from Adrian Ichim and other laboratory staff. 


\section{References}

[1] D. Stern, Explaining changes in global sulfur emissions: an econometric decomposition approach, Ecological Economics 42 (2002) 201-220. doi:10.1016/S0921-8009(02)00050-2.

[2] S. Yeh, An empirical analysis on the adoption of alternative fuel vehicles: the case of natural gas vehicles, Energy Policy 35(11) (2007) 5865-5875. doi:10.1016/j.enpol.2007.06.012.

[3] Gambhir, A. and Napp, T.A. and Emmott, C. and Anandarajah, G. , India's $\mathrm{CO}_{2}$ emissions pathways to 2050: Energy system, economic and fossil fuel impacts with and without carbon permit trading, Energy 77 (2014) $791-801$. doi:doi.org/10.1016/j.energy.2014.09.055.

[4] K. Morganti, T. Foong, M. Brear, G. da Silva, Y. Yang, F. Dryer, The Research and Motor octane numbers of Liquefied Petroleum Gas (LPG), Fuel 108 (2013) 797-811. doi:10.1016/j.fuel.2013.01.072.

[5] K. Morganti, A Study of the Knock Limits of Liquefied Petroleum Gas (LPG) in Spark-Ignition Engines, Ph.D. thesis, The University of Melbourne (December 2013). URL http://repository.unimelb.edu.au/10187/18135

[6] K. Morganti, M. Brear, G. da Silva, Y. Yang, F. Dryer, The autoignition of Liquefied Petroleum Gas (LPG) in sparkignition engines, Proceedings of the Combustion Institute 35(3) (2015) 2933-2940. doi:10.1016/j.proci.2014.06.070.

[7] M. Aslam, H. Masjuki, M. Kalam, H. Abdesselam, T. Mahlia, M. Amalina, An experimental investigation of CNG as an alternative fuel for a retrofitted gasoline vehicle, Fuel 85(5-6) (2006) 717-724. doi:10.1016/j.fuel.2005.09.004.

[8] E. Pipitone, A. Beccari, A Study on the Use of Combustion Phase Indicators for MBT Spark Timing on a Bi-Fuel Engine, SAE Technical Paper 2007-24-0051. doi:10.4271/2007-24-0051.

[9] K. Zeng, Z. Huang, B. Liu, L. Liu, D. Jiang, Y. Ren, J. Wang, Combustion characteristics of a directinjection natural gas engine under various fuel injection timings, Applied Thermal Engineering 26(8) (2006) 806-813. doi:10.1016/j.applthermaleng.2005.10.011.

[10] M. Kalam, H. Masjuki, An experimental investigation of high performance natural gas engine with direct injection, Energy 36(5) (2011) 3563-3571. doi:10.1016/j.energy.2011.03.066.

[11] J. Wang, Z. Huang, Y. Fang, B. Liu, K. Zeng, H. Miao, D. Jiang, Combustion behaviors of a direct-injection engine operating on various fractions of natural gas-hydrogen blends, International Journal of Hydrogen Energy 32(15) (2007) 3555-3564. doi:10.1016/j.ijhydene.2007.03.011.

[12] Z. Huang, J. Wang, B. Liu, K. Zeng, J. Yu, D. Jiang, Combustion Characteristics of a Direct-Injection Engine Fueled with Natural Gas-Hydrogen Blends under Various Injection Timings, Energy \& Fuels 20(4) (2006) 1498-1504. arXiv:https://doi.org/10.1021/ef060032t, doi:10.1021/ef060032t.

[13] S. Orhan Akansu, Z. Dulger, N. Kahraman, T. Nejat Veziroglu, Internal combustion engines fueled by natural gashydrogen mixtures, International Journal of Hydrogen Energy 29 (14) (2004) $1527 \quad-\quad 1539$. doi:https://doi.org/10.1016/j.ijhydene.2004.01.018.

URL http://www.sciencedirect.com/science/article/pii/S0360319904000710

[14] G. Kalghatgi, I. Algunaibet, K. Morganti, On Knock Intensity and Superknock in SI Engines, SAE Int. J. Engines 10(3). doi:10.4271/2017-01-0689.

[15] G. Kalghatgi, K. Morganti, I. Algunaibet, M. Sarathy, R. Dibble, Knock Prediction Using a Simple Model for Ignition Delay, SAE Technical Paper 2016-01-0702. doi:10.4271/2016-01-0702.

[16] E. Pipitone, S. Beccari, Performances improvement of a SI CNG bi-fuel engine by means of double-fuel injection, SAE Technical Paper. 2009-24-0058. doi:10.4271/2009-24-0058.

[17] E. Pipitone, S. Beccari, Performances and emissions improvement of an SI engine fuelled by LPG/gasoline mixtures, SAE Technical Paper 2010-01-0615. doi:10.4271/2010-01-0615.

[18] K. Morganti, M. Al-Abdullah, A. Zubail, Y. Viollet, R. Head, J. Chang, G. Kalghatgi, Improving the Efficiency of 
Conventional Spark-Ignition Engines Using Octane-on-Demand Combustion. Part I: Engine Studies, SAE Technical Paper 2016-01-0679. doi:10.4271/2016-01-0679.

[19] K. Morganti, A. Alzubail, M. Abdullah, Y. Viollet, R. Head, J. Chang, G. Kalghatgi, Improving the Efficiency of Conventional Spark-Ignition Engines Using Octane-on-Demand Combustion. Part II: Vehicle Studies and Life Cycle Assessment, SAE Technical Paper 2016-01-0683. doi:10.4271/2016-01-0683.

[20] K. Morganti, Y. Viollet, R. Head, G. Kalghatgi, M. Al-Abdullah, A. Alzubail, Maximizing the benefits of high octane fuels in spark-ignition engines, Fuel 207 (2017) 470-487. doi:10.1016/j.fuel.2017.06.066.

[21] K. Morganti, M. Al-Abdullah, A. Alzubail, G. Kalghatgi, Y. Viollet, R. Head, A. Khan, A. Abdul-Manan, Synergistic engine-fuel technologies for light-duty vehicles: Fuel economy and Greenhouse Gas Emissions, Appl. Energy 208 (2017) 1538-1561. doi:10.1016/j.apenergy.2017.08.213.

[22] K. Morganti, M. Almansour, A. Khan, G. Kalghatgi, S. Przesmitzki, Leveraging the benefits of ethanol in advanced engine-fuel systems, Energy Conversion and Management 157 (2018) 480-497. doi:10.1016/j.enconman.2017.11.086.

[23] L. Pizzuti, C. Martins, L. dos Santos, D. Guerra, Laminar Burning Velocity of Methane/Air Mixtures and Flame Propagation Speed Close to the Chamber Wall, Energy Procedia 120 (2017) 126-133. doi:10.1016/j.egypro.2017.07.145.

[24] L. Viglione, Analysis of injection, mixture formation and combustion processes for innovative CNG Engines, Ph.D. thesis, Politecnico di Torino, Politecnico di Torino (2017). doi:10.6092/polito/porto/2690247.

[25] E. Singh, M. Ali, A. Ichim, K. Morganti, R. Dibble, Effect of mixture formation and injection strategies on stochastic pre-ignition, Submitted to 2018 SAE International PF\&L Meeting.

[26] Intergovernmental Panel on Climate Change, IPCC Fourth Assessment Report (AR4), Tech. rep., Geneva, Switzerland (2007).

[27] Z. Yang, S. Rao, Y. Wang, J. Harsulkar, E. Ansari, N. Narasimhamurthy, P. Dice, J. Naber, Y. Lonari, S. Szwaja, Investigation of Combustion Knock Distribution in a Boosted Methane: Gasoline Blended Fueled SI Engine, SAE Technical Paper 2018-01-0215. doi:10.4271/2018-01-0215.

[28] J. Naber, S. Szwaja, Statistical Approach To Characterize Combustion Knock in the Hydrogen Fulled SI Engine, Journal of KONES Powertrain and Transport 14(3).

[29] J. Naber, J. Blough, D. Frankowski, M. Goble, J. Szpytman, Analysis of Combustion Knock Metrics in Spark-Ignition Engines, SAE Technical Paper 2006-01-0400. doi:10.4271/2006-01-0400.

[30] G. Kalghatgi, K. Morganti, I. Algunaibet, Some insights on the stochastic nature of knock and the evolution of hot spots in the end-gas during the engine cycle from experimental measurements of knock onset and knock intensity, SAE Technical Paper 2017-01-2233. .

[31] C. Dahnz, K. Han, U. Spicher, M. Magar, R. Schiessl, U. Maas, Investigations on Pre-Ignition in Highly Supercharged SI Engines, SAE Int. J. Engines 3(1) (2010) 214-224. doi:10.4271/2010-01-0355

[32] M. Krieck, M. Gnther, S. Pischinger, U. Kramer, M. Thewes, Effects of LPG Fuel Formulations on Knock and Pre-Ignition Behavior of a DI SI Engine, SAE Int. J. Engines 9(1) (2016) 237-251. doi:10.4271/2015-01-1947.

[33] European Automobile Manufacturers Association, Real Driving Emissions Test. Brussels, Belgium (2018). URL http://www.acea.be/industry-topics/tag/category/real-driving-emissions-test

\section{Nomenclature}

aTDC: After top dead center

bTDC: Before top dead center

BMEP: Brake mean effective pressure 
CAD: Crank angle degrees

CA50: Crank angle at which $50 \%$ of the fuel mass has been burned

$\mathrm{CO}_{2}$ : Carbon dioxide

$\mathrm{CO}_{2}$-e: $\mathrm{CO}_{2}$-equivalent emissions

$\mathrm{CH}_{4}$ : Methane

DI: Direct injection

$\mathrm{g} / \mathrm{kWh}$ : Grams of fuel consumed per kilowatt hour

GHG: Greenhouse gas

GREET: Greenhouse gases, regulated emissions, and energy use in Transportation model H/C: Hydrogen-to-carbon ratio

IMEP: Indicated mean effective pressure

ISFC: Indicated specific fuel consumption

LHV: Lower heating value

MBT: Minimum spark advance for best torque

MON: Motor octane number

$\mathrm{N}_{2} \mathrm{O}$ : Nitrous oxide

$\mathrm{NO}_{X}$ : Nitrogen oxides

PFI: Port-fuel injection

RON: Research octane number

RDE: Real Driving Emissions

rpm: Revolutions per minute

SG: Specific gravity

$\% \mathrm{v} / \mathrm{v}$ : Volume fraction

$\lambda$ : Relative air-fuel ratio 